\title{
Computer Multimedia Assisted English Vocabulary Teaching Courseware
}

\author{
https://doi.org/10.3991/ijet.v12.i12.7955 \\ Nan Yue \\ Beihua University, Jilin, China \\ annebrown959@163.com
}

\begin{abstract}
English vocabulary is often regarded as the most boring link in English learning. However, English vocabulary is the basis of all aspects of English learning. Therefore, enriching the process of English vocabulary learning and stimulating the interest of English vocabulary learning are the keys to the reform of English vocabulary teaching. The computer multimedia is developing and popularizing rapidly with the rapid development of informationization and networking, which plays its role in more and more fields. The application of multimedia technology in the field of teaching is no longer strange. This paper mainly studied the design of computer multimedia assisted English vocabulary teaching courseware. First of all, this paper gave an overview of computer multimedia technology from the aspects of concept, characteristics, development and application situation, which cited and analyzed the cognitive learning theory and memory law. Under the guidance of scientific laws and in combination with the requirement analysis and pattern construction of English vocabulary teaching, this paper realized the module design, style design and database design of English vocabulary courseware. Finally, the content of English vocabulary teaching courseware was demonstrated, and its application effect was verified through the combination of subjective evaluation and objective evaluation. This article has an important guiding significance for stimulating students' interest in English vocabulary learning and enhancing the quality of vocabulary teaching.
\end{abstract}

Keywords-English vocabulary, computer multimedia, teaching courseware, cognitive theory, memory law

\section{Introduction}

As the most widely used language in the world, English plays a more and more important role in global integration. In order to cultivate students with better English proficiency, China's reform of English teaching has never stopped [1]. With the rapid development of computer technology and the popularization of the Internet, the use of modern educational technology to enrich teachers' teaching methods and the use of the convenience of computer network to optimize English teaching pattern has become the trend of education reform and development [2-3]. 
There are many aspects of English teaching reform. This paper mainly studies the reform of English vocabulary teaching. English vocabulary is the basis of English learning. However, the rote memorization in traditional English teaching is the only way of vocabulary learning. The learning of learners is passive, whose interest in learning is very low, and the process of learning is boring [4]. Therefore, the reform of English vocabulary must enrich the learning style of English vocabulary and stimulate the interest of students.

The history of the application of computer multimedia technology in the field of education has been three decades, and the computer multimedia technology is playing a more and more diverse, abundant and interactive role in education with the progress of computer technology [5].

First of all, this paper gave an overview of computer multimedia technology from the aspects of concept, characteristics, development and application situation, and then emphatically explained the cognitive learning theory and memory law, which was taken as the foundation of English vocabulary teaching courseware design. Finally, after giving full consideration for teaching requirements and mode construction, this paper realized the design of computer multimedia assisted English vocabulary courseware and the content of related courseware was demonstrated. This research transformed the traditional teaching mode, improved memory efficiency, optimized teaching results and was of important guiding significance for the teaching reform of English vocabulary [6]. Finally, the effectiveness of designed English vocabulary courseware was verified through the combination of subjective and objective evaluation of the application effect.

\section{Overview of multimedia assisted English vocabulary teaching technology}

\subsection{Multimedia technology}

Concept of multimedia. Multimedia means multiple media, which is a combination of "multiple" and "media". Media is the carrier and expression of people's transmission of information. In accordance with international standards, the media can be divided into: (1) sensory media; (2) presentation media; (3) display media; (4) storage media; (5) communication media. Each media has its unique way and function of information transmission, and there is a relative complementary relationship between them. Nowadays, the dissemination of information has transformed from the single transmission form of sound, pictures and images into an efficient, accurate and convenient multimedia model for transmitting information [7].

Characteristics of multimedia . Multimedia is a companion to the rapid development of computer technology, which has:

1. Diversity. Diversity refers to the diversification and multiple dimensionalization in information transmission of multimedia technology. 
2. Interactivity. Interactive represents the ability to conduct interactive communication with the audience. The goal of interactivity is to enable users to control and use the information more effectively [8].

3. Integration. Integration includes two aspects, one being the integration of media devices and the other being the integration of multimedia information.

4. Real-time. Real-time means that audio, video, animation, and the like in multimedia are all connected with each other in time to make the audience feel consistent in their senses [9].

5. High-quality. The multi-media technology based on digitization can guarantee the high quality and accuracy of information transmission.

Application of multimedia. Since the 1980s, developed countries such as Britain and the United States have tried to apply multimedia technology into education. With the use of audio, video, text, slides and other materials, students' interest in learning is enhanced [10]. With the development of computer technology, the use of computers to complete multimedia courseware has become more and more popular. The production of multimedia courseware is continuously improved and it is possible to create beautiful and practicable multimedia courseware. Meanwhile, multimedia electronic publications, such as audio dictionary, encyclopedia are also the application field of multimedia. People can even find the application of multimedia in computer entertainment - games - movies. The visual browser interface of multimedia technology is shown Figure 1.

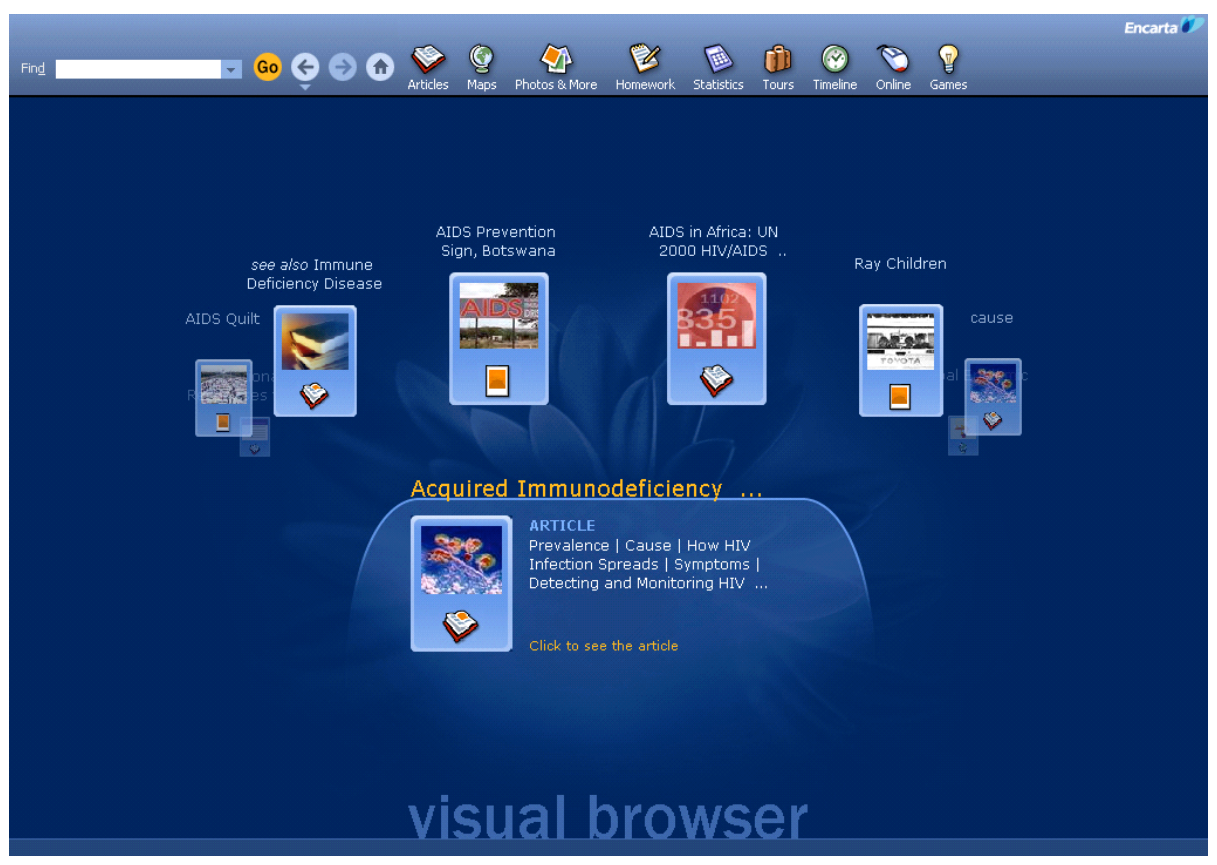

Fig. 1. The visual browser 
This article mainly conducted the in-depth study the application of multimedia technology in the field of education and used multimedia technology to assist English vocabulary teaching courseware.

\subsection{Cognitive learning theory and memory law}

Cognitive constructivism learning theory. Constructivism learning theory thinks that students are the active constructors rather than passive recipients of learning. Students are required to become the main body of information processing rather than passive indoctrination of knowledge and teachers need to change from imparting knowledge to guiding and counseling students, becoming the helper and instructor of constructive learning [11].

Ebbinghaus memory law. Ebbinghaus is the first person to discover the law of memory forgetting. He took himself as a test object and by selecting irregular syllables and random combination of letters, he obtained a set of data through his own memory of these syllables and letters. Through repeated tests and the conclusion of the law of the data, Ebbinghaus depicted a curve, which was the famous curve that revealed the law of forgetting, as is shown in Figure 2:

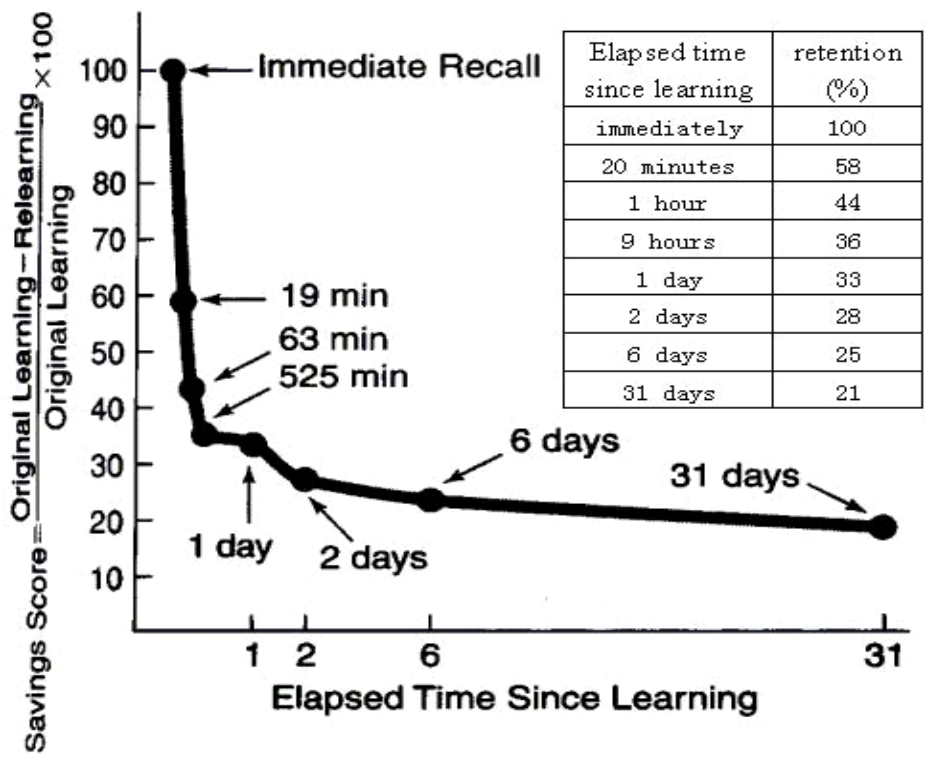

Fig. 2. Ebbinghaus forgetting curve

The process of memory forgetting is unbalanced. The amount of forgetting is different each day. The rate of forgetting is the fastest in the first day, and then gradually slows down and becomes long-term memory [12]. The forgetting curve shows that the English vocabulary teaching courseware design should be equipped with the function module of circulating practice. Through timely repeated reviewing, the words and sentences can achieve long-term memory effect and will no longer be forgotten. 


\section{Requirement analysis and model construction of multimedia assisted English vocabulary teaching}

\subsection{Requirement analysis of English vocabulary teaching}

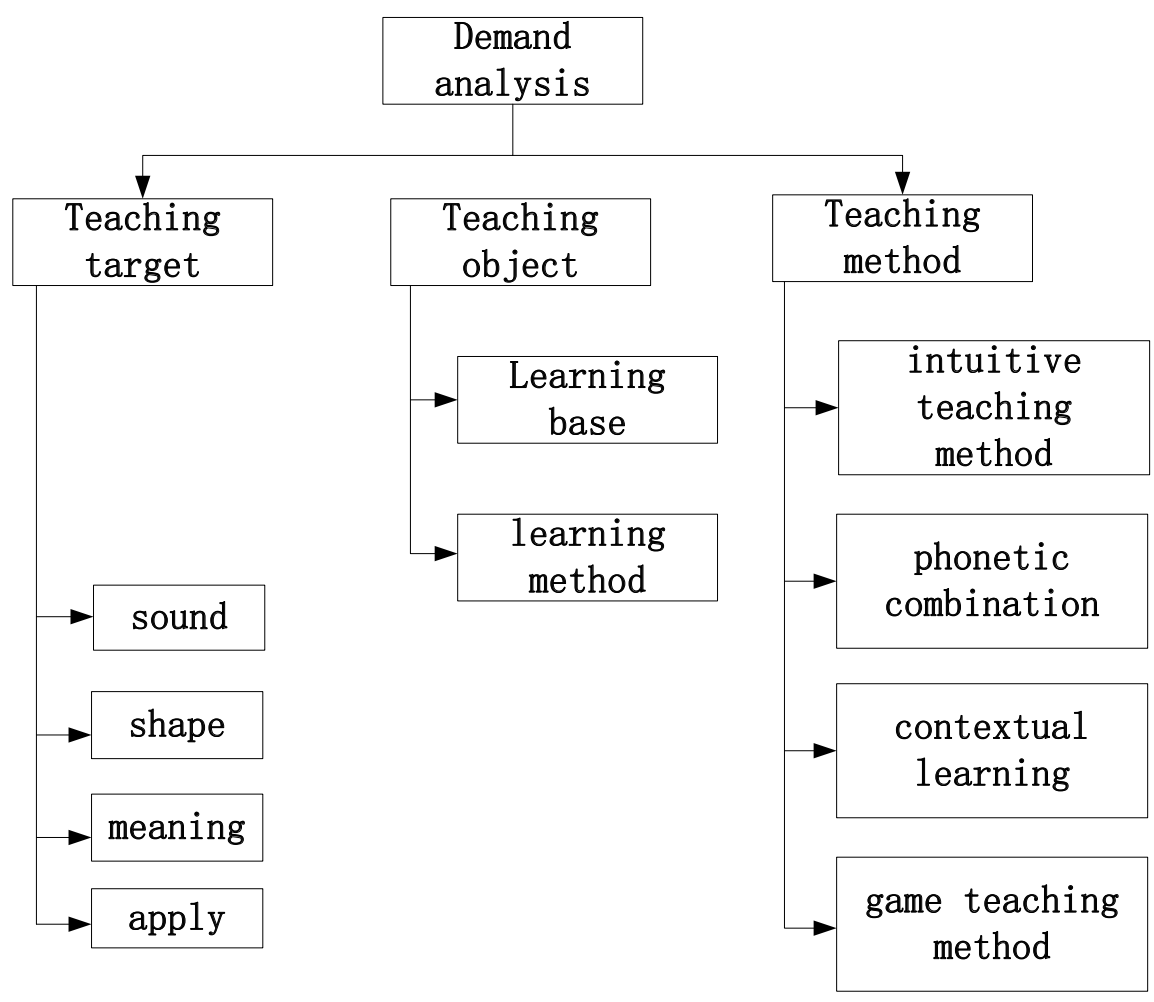

Fig. 3. Demand analysis

Vocabulary is one of the three major elements of language and the basic material of the language, there is no language without the vocabulary. The correct understanding and mastery of English vocabulary is to express their own point of view, the basis for effective communication. Vocabulary teaching is a necessary and fundamental link of English teaching [13]. The requirement of English vocabulary teaching courseware is shown in Figure 3.

Requirement Analysis of Teaching Objective. The mastery of the pronunciation, spelling, meaning and usage of vocabulary is the objective of English vocabulary teaching. Although large amount of vocabulary is beneficial for English learners, but the level of vocabulary learning and the ability of mastery is also the key. The learners should master appropriate vocabulary within their own abilities. For highfrequency vocabulary, leaners need to make a comprehensive explanation and practice from the tone, form, meaning and usage of the vocabulary [14]. 
Requirement Analysis of Teaching Objects. Mechanical vocabulary memory mode is unpopular among students, and rigid requirements for teaching are prone to give rise to the rebelliousness of students. How to use fresh teaching materials and means to improve students' interest in vocabulary learning is the key to the needs of teaching objects. In this paper, 50 students from the tourism major of Experimental College in Beijing University of Technology of 2015 was taken as the survey object, and the statistics of their English vocabulary achievement at the time of admission was shown in Table 1.

Table 1. Student English achievement of entrance distribution table

\begin{tabular}{|l|c|c|}
\hline \multicolumn{1}{|c|}{ score range } & number of people & proportion \\
\hline $0-90$ (pass) & 45 & $90 \%$ \\
\hline $91-120$ (well) & 5 & $10 \%$ \\
\hline $120-150$ (excellent) & 0 & $0 \%$ \\
\hline
\end{tabular}

It can be seen from the table that students in Grade 15 have a generally lower grade in English vocabulary and are not interested in the traditional rote vocabulary learning model. Therefore, multimedia technology should be used as a supplement to help achieve a new breakthrough in vocabulary teaching.

Requirement Analysis of Teaching Resources. "English for Tourism" is the major English textbook for this department of students. It has the characteristics of unique ideas, extensive contents and strong practicality but the learning materials are scarce. Teachers are required to supplement the teaching materials during the preparation of the courseware and use multimedia technology to enrich English vocabulary learning content [15].

\subsection{Construction of teaching model}

Through the use of different methods and forms to organize classroom activities, the enthusiasm and initiative of students are aroused. The design of English teaching activities in this article is shown in Table 2.

Table 2. Design of teaching activity

\begin{tabular}{|l|l|l|}
\hline \multicolumn{1}{|c|}{ Classroom activities } & \multicolumn{1}{|c|}{ Organizational form } & \multicolumn{1}{|c|}{ Functional effect } \\
\hline Extensive reading words & $\begin{array}{l}\text { Lead the students to read, to prepare for } \\
\text { future learning activities }\end{array}$ & $\begin{array}{l}\text { The initial understanding of the } \\
\text { vocabulary of the sound and } \\
\text { meaning }\end{array}$ \\
\hline $\begin{array}{l}\text { Fill in the blanks with the } \\
\text { letters }\end{array}$ & $\begin{array}{l}\text { Remove the individual letters in the word } \\
\text { and recall the whole word }\end{array}$ & $\begin{array}{l}\text { Remove the individual words in } \\
\text { the word and recall the whole } \\
\text { word }\end{array}$ \\
\hline Guessing word & $\begin{array}{l}\text { Give the English annotation of the word, } \\
\text { ask the student to guess the word and write } \\
\text { the correct answer }\end{array}$ & $\begin{array}{l}\text { Deepen the memory of the target } \\
\text { vocabulary meaning }\end{array}$ \\
\hline $\begin{array}{l}\text { Translate and sentence- } \\
\text { making }\end{array}$ & $\begin{array}{l}\text { Require students to make sentences or } \\
\text { translations of the specified words to the } \\
\text { Chinese sentence }\end{array}$ & $\begin{array}{l}\text { Master the context and usage of } \\
\text { words }\end{array}$ \\
\hline
\end{tabular}


Vocabulary is the basic unit of the sentence, so the context of the sentence is also the key to learning vocabulary. For certain words, such as "first-time visitors", the context should be set and relevant reference video and PPT can be provided to students through the use of multimedia. Students are required to complete the classroom presentation in a role-playing style [16]. Evaluation methods should not be limited to dictation test but adopt multimedia vocabulary to conduct computer tests or network tests to improve the freshness of vocabulary learning.

\section{Design, realization and evaluation of multimedia assisted English vocabulary teaching courseware}

\subsection{Design of multimedia assisted English vocabulary teaching courseware}

Module design. The modules of the courseware mainly include easy read, easy explain, easy remember and easy use. The function structure diagram is shown in Figure 4.

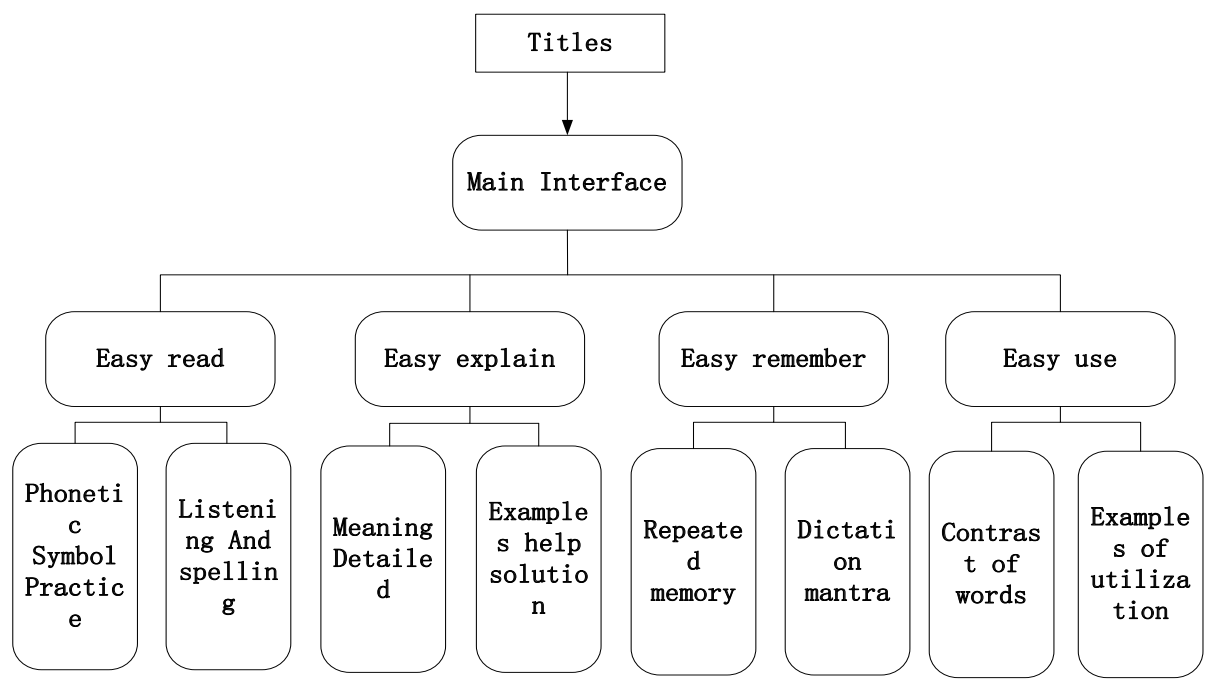

Fig. 4. The framework of easy vocabulary

Style design and database design. The main style of English vocabulary teaching courseware is simple, elegant, beautiful and dynamic. After text, images, audio, video, background music and animation collection, these materials are processed and will be imported into the courseware when achieving the desired effect.

Due to the fact that the English courseware does not need to access the external Internet during the presentation process, the database uses the Access database as its database while storing the information. The storage of data is achieved through the database filed. 
Id field is the sequence number of storage words; the word field is the primary key of the field; unit is the unit where the word is located; property is field of the part of speech of words; example is the example sentence field, remarks is the word storage of other information.

Table 3. The database filed design

\begin{tabular}{|c|c|c|}
\hline Field name & Description & Type \\
\hline id & Word serial number & Autonumber \\
\hline word & Word body & Text \\
\hline unit & Subordinate units & Text \\
\hline property & Word attribute & Text \\
\hline explain & Chinese meaning & Text \\
\hline example & example sentence & Text \\
\hline remarks & Note & \\
\hline
\end{tabular}

\subsection{Realization of multimedia assisted English vocabulary teaching courseware}

Manufacturing technology. Multimedia assisted English vocabulary teaching courseware relies on many of the manufacturing techniques, and appropriate English courseware manufacturing technology is of great help for the courseware display effect and teaching effect. The techniques which are more widely used are the following:

1. Video and audio synthesis software: Adobe Premiere, Ulead MediaStudio, Super Audio Pa, Goldwave and Soundforge.

2. Image editing software: Adobe Photoshop, PhotoImpact, which can be used to process static images.

3. multimedia manufacturing software. Multimedia manufacturing is the core of manufacturing courseware, and the commonly used software includes Power Point, Macromedia flash, Dreamweaver.

Realization and presentation of main interface. Figure 5 is the main interface of English courseware. The main page of multimedia assisted English vocabulary teaching courseware bears the principle of simple and elegant. By clicking the options on the main interface, students can learn English vocabulary form the aspects of reading, explanation, remembering and use.

Figure 6 shows the explanation of vocabulary in the example sentence in the easy explain module. The courseware is divided into eight units of vocabulary explanation learning, including an explanation of over 4,000 commonly used words.

In addition, teachers can search for relevant vocabulary to explain to students based on the needs of students. In the easy to read, easy to remember, easy to use module, English vocabulary courseware can provide teaching modes like phonetic spelling, listening to tell words, repeated memory, dictation to help memorize, meaning comparison, use of example sentences, providing students with the help in English listening, writing, speaking and using. 


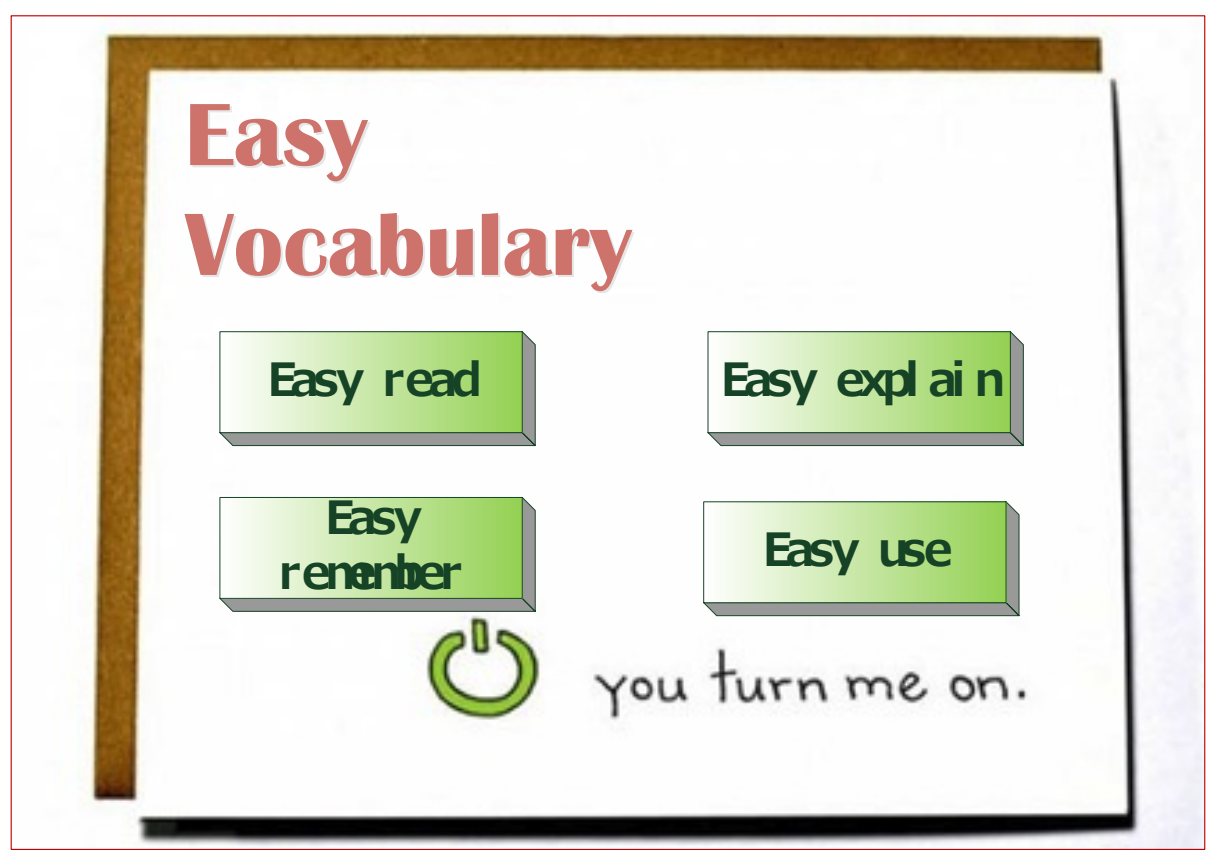

Fig. 5. The main interface of the English courseware

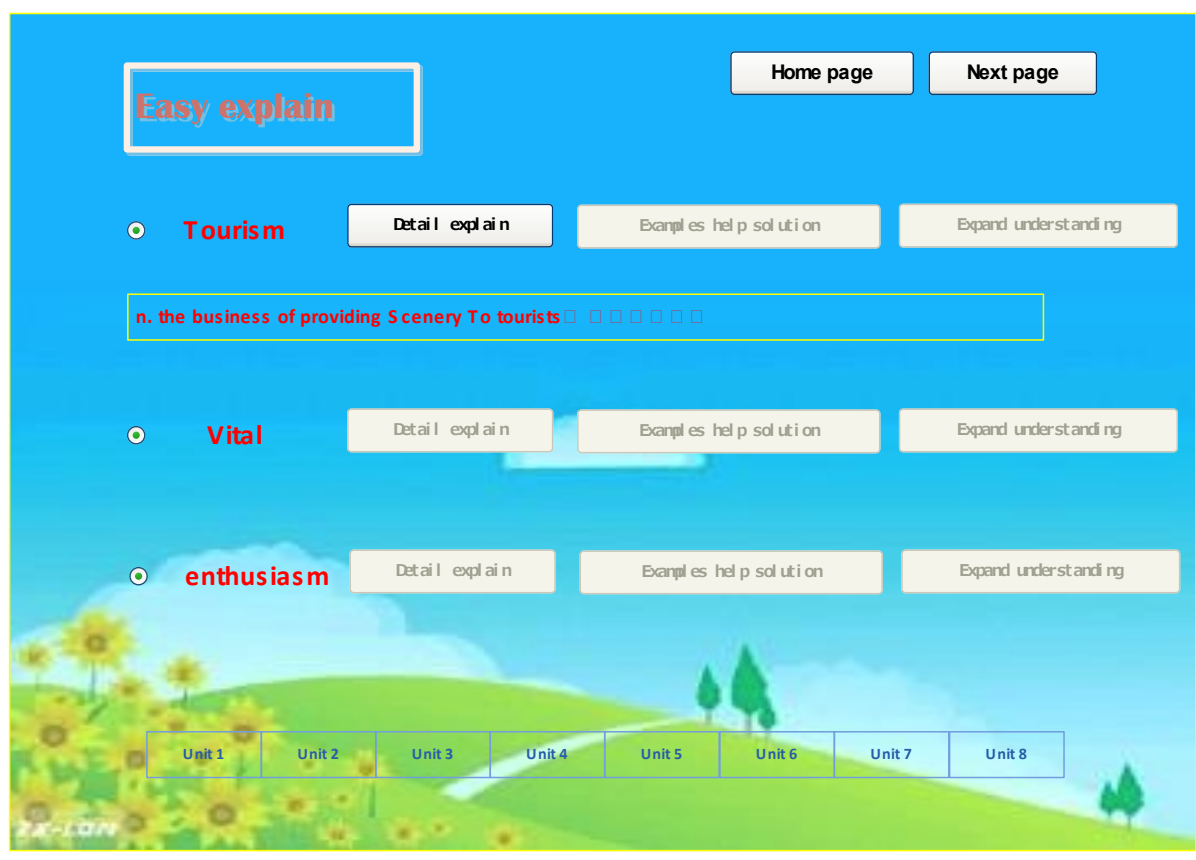

Fig. 6. The interface of easy explain 
This display mode of multimedia vocabulary courseware can better realize the interaction function, and the information exchange and transmission between student and teacher, teacher and computer multimedia, and student and computer multimedia can be smoother. Each module in the English vocabulary teaching courseware can cooperate with each other to provide students with required learning activities and even exercises, which will play a positive role in improving the students' English vocabulary and learning interests.

\subsection{Evaluation of multimedia assisted English vocabulary teaching courseware}

Subjective evaluation. Through the subjective survey of 50 students in the tourism major of 2015 participating in the training of English vocabulary courseware, more than $50 \%$ of students think multimedia assisted vocabulary teaching has brought new changes to the classroom, which are practical, functional and more attractive. More than $70 \%$ of the students think that the interactive environment in the classroom is better. Through human-computer interaction, the listening, speaking, reading and writing of new words can be more smoothly and the practice and memory of vocabulary can be more profound.

Objective evaluation. The comparison of the dictation results of the experimental class in the longitudinal direction of time is used to objectively evaluate the effect of the multimedia assisted English vocabulary teaching courseware. Table 4 shows the statistics of average performance of students' dictation.

As it can be seen from the table that the dictation of English vocabulary in last semester was about 50, and the average score improved to 70 in this semester, which was a $34 \%$ progressive rate. This objectively demonstrated that the multimedia assisted English vocabulary teaching courseware has a positive effect on the improvement of students' English vocabulary.

Table 4. The statistical table of dictation scores

\begin{tabular}{|c|c|c|c|c|c|}
\hline Time & & Dictatio & ver & & Progress ratio \\
\hline This semester & 72 & 70 & 75 & 69 & \multirow{2}{*}{$34 \%$} \\
\hline Last semester & 54 & 56 & 52 & 51 & \\
\hline
\end{tabular}

\section{Conclusion}

English vocabulary is the most basic part of English learning. In order to get rid of the boring and inefficient learning of English vocabulary in the traditional teaching mode, this paper applies computer multimedia technology to the design and manufacture of English vocabulary teaching courseware. First of all, this paper introduces the development and application of multimedia technology and then describes the cognitive learning theory and memory law abided by the courseware design. Based on this, this paper analyzes the requirements, styles and databases of the courseware, and finally implements and displays the multimedia English vocabulary teaching course- 
ware, verifying its application effect. This paper has the following conclusions and application significance:

1. The English vocabulary courseware based on cognitive learning theory and Ebbinghaus's memory law can meet the requirement of vocabulary memory functionally.

2. The multimedia English translation vocabulary teaching can achieve good humancomputer interaction effect and good application effect, and can assist vocabulary teaching, which is also a great help to improve the vocabulary of students. Thus, this teaching mode should be applied and popularized.

\section{$6 \quad$ References}

[1] Gong, Y.J. (2012). On current situation of the oral English teaching in higher education and its improving measures. American Journal of Human Genetics, 90(6): 941-949.

[2] Zhao, X.G., Yang, Y.H. (2015). The current situation of shale gas in Sichuan, China. Renewable \& Sustainable Energy Reviews, 50: 653-664. https://doi.org/10.1016/j.rser.2015.0 $\underline{5.023}$

[3] Le, Y. (2011). Application of computer and multimedia technology in college physical education. IEEE. DOI: /10.1109/paccs.2011.5990343.

[4] Aceves, J.J.G.L., Poggio, A.A. (2006). Computer-based multimedia communications. Computer, 18(10): 10-11. https://doi.org/10.1109/MC.1985.1662709

[5] Fengxiang, F. (2010). An asymptotic model for the English hapax/vocabulary ratio. Computational Linguistics, 36(4): 631-637. https://doi.org/10.1162/coli a 00013

[6] Reanjaroensuk, P. (2014). An investigation into the English vocabulary proficiency in a natural science context of first year arts and science oriented university students /panitda reanjaroensuk. Journal of Chemical Physics, 140(22): 345-59.

[7] Wijayanti, D. (2013). The vocabulary mastery of the elementary level students of the center of English language learning (cell) course pati in academic year 2012/2013 taught by using interactive power point games. Skripsi: Experimental Gerontology, 42(8): 713-718.

[8] Kudiavtseva, S., Kolos, V., Kommers, P.A.M. (2001). Development of the methodology of applying multimedia means for distance courseware design, development and implementation. Journal of Immunological Methods, 205(2): 145-150.

[9] Yamamoto, H., Higashibara, Y. (2013). Design of a multimedia courseware for learning gymnastics in elementary school. Journal of Horticultural Science \& Biotechnology, 88(2): 179-186.

[10] Dixon, J.L., Mukhopadhyay, D., Hunt, J., Jupiter, D., Smythe, W.R., Papaconstantinou, H. T. (2016). Enhancing surgical safety using digital multimedia technology. American Journal of Surgery, 211(6): 1095-1098. https://doi.org/10.1016/j.amjsurg.2015.08.023

[11] Stern, J.M. (2014). Cognitive constructivism and the epistemic significance of sharp statistical hypotheses in natural sciences. Statistics, 58(2): 123-127

[12] Shebilske, W., Ebenholtz, S.M. (1971). Ebbinghaus' derived-list experiments reconsidered. Psychological Review, 78(6): 553-555. https://doi.org/10.1037/h0031819

[13] Oktafiani, N., Siska, S., Ikhsan, M.K. (2005). An analysis of professional English teacher as facilitator in teaching and learning process a study of English teacher at smpn 1 pantai cermin and mtsn gaduang surian pantai cermin. Physical Review Letters, 94(7): 1-4.

[14] Permatasari, S.E., Suryadi, H.S. (2011). Teaching English vocabulary using pictures and songs to the young learners: a comparative study at tk. kalpataru bintaro. Biotechnology Advances, 8(8): 672 . 
[15] Mohan, K.G. (2006). A factual analysis of the major issues in teaching English at the undergraduate level in Kerala, to design a need based new curriculum. Journal of Seismology, 14(2): 309-337.

[16] Miressa, A. (2014). An assessment of the practice of vocabulary teaching strategies in EFL classes: Kellem secondary school grade 9 and 10 English teachers in focus. Oncogene, 33(8): 986-95.

\section{$7 \quad$ Author}

Nan Yue is with Normal English department, Foreign Language College, Beihua University, Jilin 132013, China.

Article submitted 09 November 2017. Published as resubmitted by the authors 13 December 2017. 